\title{
Proposed Protocol for a Rare Plant Survey in the Lower Foothills, Northern East Slopes Region
}

\author{
Beth Cornish
}

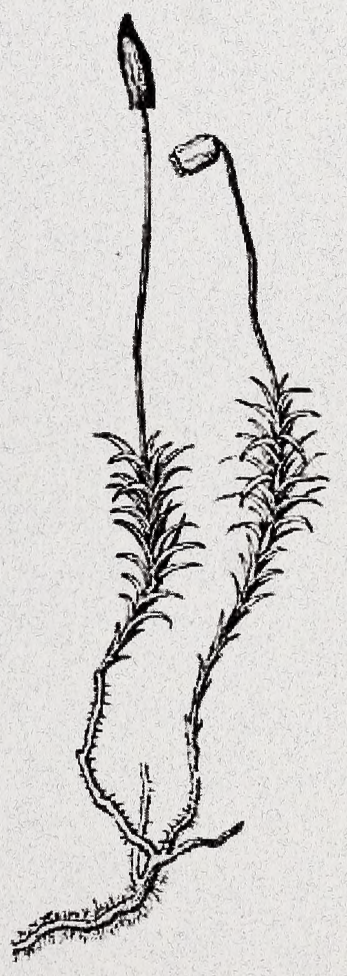


Digitized by the Internet Archive in 2016 


\section{Proposed Protocol for a Rare Plant Survey in the Lower Foothills, Northern East Slopes}

Beth Cornish

Alberta Species at Risk Interim Report

March 2001

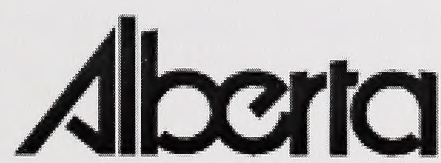

SUSTAINABLE RESOURCE

DEVELOPMENT 
Publication No.: $\mathrm{I} / 014$

ISBN: 0-7785-1773-X (Printed Edition)

ISBN: 0-7785-1774-8 (On-line Edition)

This publication may be cited as:

Cornish, Beth. 2001. Proposed protocol for a rare plant survey in the lower foothills, Northern East Slopes. Alberta Sustainable Resource Development. Fisheries and Wildlife Management Division, Edmonton, AB, Interim Report. 


\section{TABLE OF CONTENTS}

1.0 INTRODUCTION

2.0 STUDY AREA 1

3.0 POTENTIAL RARE PLANT SPECIES AND TARGET SEARCH AREAS 1

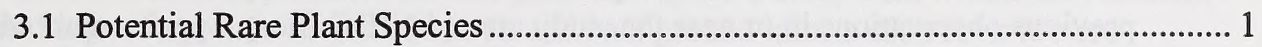

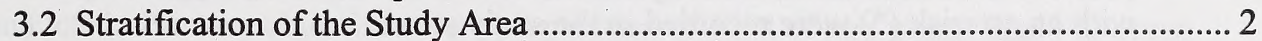

3.2.1 Priority Habitats and Landscape Features ...................................................... 2

3.2.2 Priority Geographic Areas............................................................................. 5

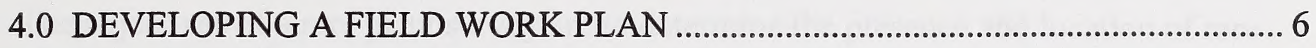

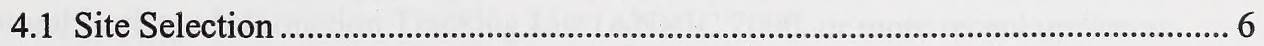

4.2 Recommended Survey Schedule .................................................................. 7

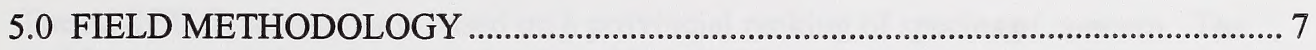

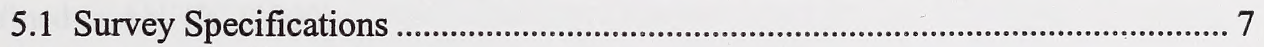

5.2 Documentation of Rare Plant Populations........................................................ 8

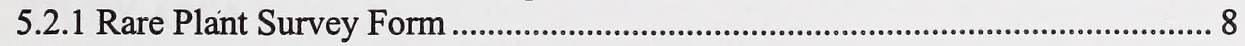

5.2.2 Location of Plots and Rare Plant Populations ................................................... 9

5.2.3 Photographs and Voucher Specimens ........................................................... 9

5.3 Rare Plant Site Descriptions .......................................................................... 10

6.0 RARE PLANT REPORT AND OTHER RECEIVABLES....................................... 10

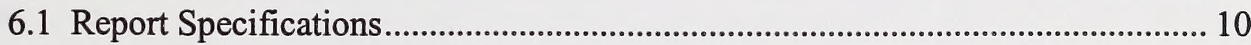

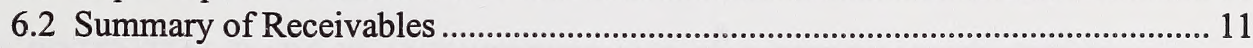

7.0 PROJECT CONSIDERATIONS AND CONSTRAINTS ........................................... 11

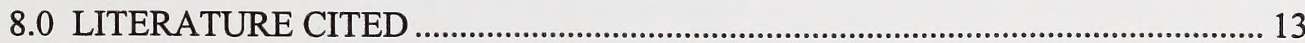

APPENDIX A. Other rare vascular plants with the potential to occur in the study area. APPENDIX B. Other bryophytes predicted to occur in the study area.

APPENDIX C. Aerial photograph coverage and Alberta Vegetation Inventory available for the study area. 


\section{LIST OF TABLES}

Table 1. Rare vascular plants recorded in or near the study area, based on element occurrence records in ANHIC files, or other studies. Species marked with an asterisk $\left(^{*}\right)$ were recorded in study area. Habitat information is from Moss (1983) unless otherwise indicated.

Table 2. Non-vascular plants recorded or predicted to occur in study area, based on previous observations in or near the study area (ANHIC files). Species marked with an asterisk $\left({ }^{*}\right)$ were recorded in the study area............................4

Table 3. Proposed number of survey sites for each target landscape feature...............7 


\subsection{INTRODUCTION}

An essential preliminary step to ensuring that rare plants and their habitat are protected is the identification and location of rare plant populations. This information can then be utilized in providing effective input for land use decisions.

In order to establish priorities for rare plant surveys in a study area within the Northern East Slopes Region, a literature search and background information review were conducted. Primary objectives were preparation of a list of rare plants likely to occur within the study area, as well as development of a sampling protocol for a future rare plant inventory within the specific Northern East Slopes study area.

The objectives of a rare plant survey are to determine the presence and location of rare plant species. Alberta rare plant species are defined as those listed on the current Alberta Natural Heritage Information Tracking List (ANHIC 2000, or more recent update as becomes available).

The ANHIC Tracking list is based on a provincial ranking of species of concern. The ranking system is based on one developed by The Nature Conservancy and the ranks are defined in ANHIC (2000).

\subsection{STUDY AREA}

The study area includes White Zone lands (managed by Alberta Agriculture, Food and Rural Development) within the Lower Foothills Natural Subregion (Achuff 1994) in an area bounded by Highways 43 and 16 between Highways 32 and 22. This region covers parts of approximately 23 townships within the following land area: Townships 53-59, Rge 8-14, W5M. Approximately $1600 \mathrm{~km}^{2}$ of land are potentially included in the study area.

\subsection{POTENTIAL RARE PLANT SPECIES AND TARGET SEARCH AREAS}

\subsection{Potential Rare Plant Species}

Lists of the rare vascular and non-vascular plants that have been identified within or near the study area are given in Tables 1 and 2 below. The assigned ranks of these species are based on the most up-to-date information in ANHIC (2000). However, these ranks are periodically reviewed, and it is expected that a review of ranks will occur prior to the 2001 field season. Therefore a review and update of these lists will be necessary prior to the field season, in light of possible changes to ranks. For example, species not currently considered rare (that is, not on the current tracking lists) could be included on future tracking lists.

Seventeen rare vascular plant species and 29 non-vascular species ( 22 bryophyte species and 7 lichen species) have been recorded in or near the study area (ANHIC occurrence 
records). These species should be considered target species for a rare plant survey. Researchers should endeavour to become especially familiar with the identification of these target species, through examination of herbarium specimens.

It is important to point out however, that although these species should be considered target or priority species for a rare plant survey in the study area, these are not necessarily the only rare plant species that occur in the study area. As an aid for rare plant researchers, Appendices A and B list additional species with the potential to occur in the study area based on known distribution in west-central Alberta or on discussions in other published documents.

\subsection{Stratification of the Study Area}

\subsubsection{Priority Habitats and Landscape Features}

With time and budget constraints and a large geographic area to be covered, it is recommended that sampling effort focus on landscape features which have the greatest potential for locating rare plants. The study area should be stratified into high and low priority plant habitats or landscape features prior to sampling. High priority sites will be those with the greatest potential to contain rare plants. Landscape features likely to contain rare plants should be highlighted or pre-plotted on air photos prior to surveys.

A review and summary of the habitats in which rare plants were recorded previously in or near the study area shows that some habitats support a greater proportion of rare plant species than other habitats. Analysis of habitats of species listed in Tables 1 and 2 and Appendices A and B shows that $38 \%$ of the vascular and $53 \%$ of the non-vascular rare plant species with the potential to occur in the study area are found in bogs or fens. However, only approximately $1 \%$ of the Lower Foothills Subregion is occupied by peatlands (Vitt et al 1998).

Forested habitats are also important target areas for rare plant searches. Mature forests in particular should be targeted because they are characterized by structural complexity and often support a variety of microhabitats which have good potential for rare plants. In a rare plants survey conducted at Fort Assiniboine Sandhills Wildland Park, the greatest concentrations of rare plants occurred in "old-growth" riparian forest (Timoney and Robinson 1998). Other landscape features that have a potential to support rare plants in the Lower Foothills include springs, eolian soils and rocky outcrops. 
Table 1. Rare vascular plants recorded in or near the study area, based on element occurrence records in ANHIC files, or other studies. Species marked with an asterisk $(*)$ were recorded in study area. Habitat information is from Moss (1983) unless otherwise indicated.

\begin{tabular}{|c|c|c|c|}
\hline Species & Common Name & SRank & Habitat \\
\hline Aster $x$ maccallae & MacCalla's aster & S1S2 & $\begin{array}{l}\text { jackpine/bearberry - northern ricegrass community } \\
\text { (Timoney and Robinson 1998) }\end{array}$ \\
\hline $\begin{array}{l}\text { Botrychium multifidum } \\
\text { var. intermedium }\end{array}$ & leather grape fern & S2 & moist, sandy areas \\
\hline Carex backii & Back's sedge & SU & dry shady woods; \\
\hline Carex houghtoniana* & sand sedge & $\mathrm{S} 2$ & dry sandy or gravelly places \\
\hline Carex pedunculata & sedge & S1 & $\begin{array}{l}\text { moist mixed forest, mostly aspen (Hudson 1977) (not } \\
\text { in Moss 1983) }\end{array}$ \\
\hline Cystopteris montana* & $\begin{array}{l}\text { mountain bladder } \\
\text { fern }\end{array}$ & S2 & springs or damp calcareous places; \\
\hline Drosera linearis* & $\begin{array}{l}\text { slender-leaved } \\
\text { sundew }\end{array}$ & S2 & bogs \\
\hline Lactuca biennis* & tall blue lettuce & S2 & moist open woods and clearings \\
\hline Luzula acuminata & wood-rush & S1 & disturbed moist woodland; \\
\hline Monotropa hypopitys & pinesap & S2 & $\begin{array}{l}\text { mossy coniferous forests (Johnson et al 1995); } \\
\text { coniferous woods (Moss 1983); }\end{array}$ \\
\hline Phegopteris connectilis & $\begin{array}{l}\text { northern beech } \\
\text { fern }\end{array}$ & S2 & moist woods; 3 dots in Moss 1983; \\
\hline Potamogeton foliosus & leafy pondweed & S2 & aquatic plant \\
\hline Potamogeton natans & $\begin{array}{l}\text { floating-leaf } \\
\text { pondweed; }\end{array}$ & S2 & aquatic plant; \\
\hline Potamogeton praelongus & $\begin{array}{l}\text { white-stem } \\
\text { pondweed }\end{array}$ & S2 & aquatic plant; occurs in deep water \\
\hline Sphenopholis obtusata & $\begin{array}{l}\text { prairie wedge } \\
\text { grass }\end{array}$ & S2 & $\begin{array}{l}\text { moist meadows, shores \& open woods; in a riparian } \\
\text { point bar thicket with river alder - shining willow - } \\
\text { yellow willow (Timoney \& Robinson 1998) }\end{array}$ \\
\hline Stellaria crispa & $\begin{array}{l}\text { wavy-leaved } \\
\text { chickweed }\end{array}$ & S2 & moist woods \\
\hline Viola pallens & $\begin{array}{l}\text { Macloskey's } \\
\text { violet }\end{array}$ & S1 & $\begin{array}{l}=V . \text { macloskeyi var. pallens of Moss 1983; moist } \\
\text { woods; }\end{array}$ \\
\hline
\end{tabular}

* previously recorded in study area 
Table 2. Non-vascular plants recorded or predicted to occur in study area, based on previous observations in or near the study area (ANHIC files). Species marked with an asterisk $(*)$ were recorded in the study area.

\begin{tabular}{|c|c|c|c|}
\hline $\begin{array}{l}\text { Species } \\
\text { a) Bryophytes }\end{array}$ & Common Name & SRank & (2: \\
\hline Aongstroemia longipes & & S2 & $\begin{array}{l}\text { found in sandy or silty soils, along McLeod River (ANHIC } \\
\text { files 2001) }\end{array}$ \\
\hline Atrichum undulatum & $\begin{array}{l}\text { undulated } \\
\text { cranes' bill moss }\end{array}$ & S1S2 & $\begin{array}{l}\text { acidic soils usually in mesic situations, often occurs with } \\
\text { Dicranella species along moist sandy trail banks (Vitt et al } \\
\text { 1988) }\end{array}$ \\
\hline Barbula coreensis & & S1 & $\begin{array}{l}\text { on calcareous substrate, in a white spruce - aspen riparian } \\
\text { forest (ANHIC files) }\end{array}$ \\
\hline Brachythecium rutabulum & & S2? & $\begin{array}{l}\text { on forest floor of white spruce - aspen rich riparian forest } \\
\text { (Timoney and Robinson 1998) }\end{array}$ \\
\hline Bryobrittonia longipes & & S3 & $\begin{array}{l}\text { moist calcareous soil along streams; on calcareous sandstone } \\
\text { in white spruce-aspen forest along creek, and sandy silty } \\
\text { riverbanks (ANHIC files); moist soil in rock crevices; (Vitt et } \\
\text { al 1988) }\end{array}$ \\
\hline Bryum algovicum & & S2 & on ground in black spruce muskeg (ANHIC files) \\
\hline Bryum uliginosum & & S1 & along creek (ANHIC files) \\
\hline Campylium polygamum & & S3 & $\begin{array}{l}\text { riparian meadow, mixedwood and balsam poplar (Timoney } \\
\text { and Robinson 1998); similar to C. stellatum but less rich sites; } \\
\text { sandy flats along edge of McLeod River (ANHIC files); }\end{array}$ \\
\hline Campylium radicale & & S2 & $\begin{array}{l}\text { bogs (Vitt et al 1988); in Ft. Assiniboine in riparian mature } \\
\text { mixed wood, riparian balsam poplar, river alder-willow } \\
\text { /horsetail (Timoney and Robinson 1998) }\end{array}$ \\
\hline Didymodon rigidulus & rigid screw moss & S2 & $\begin{array}{l}\text { on calcareous rocky substrate in white spruce - aspen riparian } \\
\text { forest (ANHIC files); }\end{array}$ \\
\hline Entodon schleicheri & & S1 & $\begin{array}{l}\text { in riparian forests (white spruce - birch -aspen) (Timoney and } \\
\text { Robinson 1998) }\end{array}$ \\
\hline Fontinalis missourica & & S1 & $\begin{array}{l}\text { on acidic rocky substrate at edge of water (rapid-flowing) } \\
\text { (ANHIC files); }\end{array}$ \\
\hline Herzogiella turfacea & & S1 & on ground in leaf litter in pine woods (ANHIC files) \\
\hline Hygroamblystegium tenax & & S1 & on stones in rapid water of creek (ANHIC files) \\
\hline Pogonatum dentatum & $\begin{array}{l}\text { hair-like } \\
\text { pogonatum }\end{array}$ & $\mathrm{S} 2 \mathrm{~S} 3$ & $\begin{array}{l}\text { as isolated individuals on disturbed acidic gravelly or sandy } \\
\text { soil and on humid cliff ledges (Vitt et al 1988) on loam of } \\
\text { uprooted tree in dense coniferous forest (ANHIC files); in } \\
\text { Pinus contorta woods (ANHIC files) }\end{array}$ \\
\hline Pohlia atropurpurea & & S1 & on sandy, silty riverbank (ANHIC files) \\
\hline Schistostega pennata & luminous moss & S1S2 & $\begin{array}{l}\text { disturbed soil on shaded roots of fallen trees in coniferous } \\
\text { forests, wet sites (e.g. lake edges) }\end{array}$ \\
\hline Seligeria donniana & $\begin{array}{l}\text { Donian beardless } \\
\text { moss }\end{array}$ & S2 & $\begin{array}{l}\text { on calcareous soil next to stream and on outcropping of } \\
\text { limestone boulders (ANHIC files) }\end{array}$ \\
\hline Sphagnum balticum & peat moss & S1 & Vitt et al (1998): bogs, poor fens; \\
\hline Splachnum ampullaceum* & $\begin{array}{l}\text { flagon-fruited } \\
\text { splachnum }\end{array}$ & S2 & $\begin{array}{l}\text { on animal dung in bogs and fens (Vitt et al 1988); and on } \\
\text { dung in moist mixedwood forest (ANHIC files) }\end{array}$ \\
\hline Splachnum rubrum & red collar moss & S2 & $\begin{array}{l}\text { on animal dung in bogs and fens (Vitt et al 1988) and on dung } \\
\text { in moist mixedwood forest (ANHIC files) - aspen-poplar- } \\
\text { birch-white spruce; }\end{array}$ \\
\hline Zygodon viridissimus & & S1 & $\begin{array}{l}\text { at Ft. Assiniboine Sandhills: forest floor of mature riparian } \\
\text { forest of white spruce - aspen / river alder - Alaska birch } \\
\text { (Timoney and Robinson 1998) }\end{array}$ \\
\hline
\end{tabular}




\begin{tabular}{|l|l|l|l|}
\hline $\begin{array}{l}\text { Table 2 (cont'd) } \\
\text { b)Lichens }\end{array}$ & & & \\
\hline Hypocenomyce friesii ${ }^{*}$ & -- & S2 & on charred log in lodgepole pine woods (ANHIC files); \\
\hline Cladonia squamosa & -- & S2 & in black spruce/labrador tea/sphagnum forest \\
\hline Melanelia multispora & -- & S2? & on trunk of balsam poplar in open creek valley \\
\hline Ramalina obtusata & -- & S2 & on bark of dead trees in dense coniferous forest \\
\hline Heterodermia speciosa & -- & S2 & $\begin{array}{l}\text { on poplar; black spruce muskeg and lodgepole pine woods; } \\
\text { also on bark of dead windfall trees in spruce forest (ANHIC } \\
\text { files) }\end{array}$ \\
\hline Peltigera horizontalis & -- & moist coniferous forests \\
\hline Cladonia cyanipes & -- & S2? & growing on humus in black spruce -tamarack forest \\
\hline
\end{tabular}

\subsubsection{Priority Geographic Areas}

The following geographic areas have either been identified as significant ecological features (Bentz and Saxena 1994) or have been set aside as protected areas (Alberta Parks and Protected Areas files). It may be an advantage to concentrate sampling effort in these areas, where the existence of target landscape features has been confirmed.

\section{McLeod River: Twp 57-59, Rge 12-13 W5M}

Classed as a provincially significant feature (Bentz and Saxena 1994) the McLeod River valley is characterized by a high diversity of fluvial landforms, including terraces, extensive meanders, point bars and oxbow lakes; diverse vegetation communities including mature mixedwood and coniferous forest and a variety of wetland and shrubland communities; soils are primarily sandy loam textured (Regosols). There are some small stands of old-growth white spruce and white spruce-balsam poplar on fluvial terraces that have not been cleared.

2. Whitecourt Natural Area Reservation: Sec SW8 and pt NE 7, Twp 59, Rge 11, W5M; This area contains a diversity of forest types including aspen-white spruce, jack pine and black spruce forest, as well as a small depressional peatland with black spruce -tamarack /sphagnum vegetation (Bentz and Saxena 1994, Alberta Parks and Protected Areas files).

\section{Beta Lake Natural Area Reservation: NE4 and E 1/2 9- Twp 55, Rge 11 W5M;}

This proposed natural area supports sedge meadows and black spruce bogs and is a good area to search for Drosera linearis (Alberta Parks and Protected Areas files).

\section{Highway Natural Area - Sec 32, Twp 55, Rge 10 W5M; 40 km SE of Whitecourt} This area contains old growth riparian deciduous and mixedwood forests on fairly steep slopes, as well as a sedge wetland (Alberta Parks and Protected Areas files).

\section{Balm Natural Area Reservation: NW22-Twp 57, Rge 9 W5M;}

The vegetation in this proposed natural area includes black spruce-tamarack bog, paper birch-aspen forest, aspen forest, low shrublands and wet meadows (Alberta Parks and Protected Areas files). 


\section{Paddle River Natural Area: SE8-Twp 56, Rge 9 W5M}

This Natural Area supports rolling upland aspen forest sloping towards the creek (Alberta Parks and Protected Areas files).

\subsection{DEVELOPING A FIELD WORK PLAN}

\subsection{Site Selection}

The proportion of rare plants predicted to occur in each habitat can be used to determine an appropriate approach to determine survey effort. Table 3 presents proposed numbers of rare plant survey sites for each target habitat or landscape feature.

Each of the recorded locations of previous occurrences of rare plants (from ANHIC files) in the study area should be field-checked to re-locate the rare plant population. The remainder of the 100 sites must be selected using available vegetation community maps, Alberta Vegetation Inventory (AVI) maps, and aerial photograph interpretation.

Detailed vegetation community mapping has not been completed for the entire study area. However, some areas have been mapped (Bentz et al 1993; Van Waas 1978), and these maps should be used to identify the location of the various target vegetation cover types. In areas where no detailed community type mapping has been completed, AVI information can be utilized. Alberta Vegetation Inventory maps are available for most parts of the study area, other than a small area of the southeast part of the study area (Twp 53, Range 10) (D. Langner, Resource Data Div., Alberta Environ., pers. comm.).

Where coverage on other maps is inadequate, aerial photographs must be interpreted and stratified to identify locations of target landscape features or vegetation cover types (such as lakes and lake shoreline areas, bogs and fens, marshes and hydrological features, grasslands, and mature forests). In addition, air photo interpretation can be used to locate other special features which may have potential to support rare plants, such as sandy areas and cliffs. It will likely not be possible to identify all potential microhabitats (such as springs) at this scale.

Details of some currently available aerial photograph coverage of the study area are given in Appendix C. Air photos are available from government sources at a scale of 1:30,000 for most of the study area, with the exception of the northeast part. The northeast part of the study area (Township 57, Ranges 11 to 13, to Township 59, Ranges 11 and 12, W5) are covered by 1:20,000 aerial photography. Additional aerial photography is also available for the study area at a smaller scale.

Representative survey sites should be selected for each target landscape or habitat type. For expediency, sites should be adjacent to one another to save travel time. For example, clusters of habitats should be sampled, such as a mature forest site adjacent to a wetland. In addition, selected sites in forested vegetation types should vary in dominant species, aspect, slope, elevation and moisture regime. 
Table 3. Proposed number of survey sites for each target landscape feature.

\begin{tabular}{|l|l|l|}
\hline Landscape Type & $\begin{array}{l}\text { Number of Sites } \\
\text { Recommended }\end{array}$ & $\begin{array}{l}\text { Recommended Month of } \\
\text { Field Survey }\end{array}$ \\
\hline Open water & 2 sites & June \\
\hline $\begin{array}{l}\text { Grasslands, } \\
\text { colluviating slopes }\end{array}$ & 8 sites & June \\
\hline Marshes and springs & 10 sites & June \\
\hline Bogs and Fens & 40 sites & July or August \\
\hline $\begin{array}{l}\text { Forests (recommended } \\
\text { mature forests to be } \\
\text { given highest priority) }\end{array}$ & 40 sites & July or August \\
\hline $\begin{array}{l}\text { TOTAL } \\
\text { RECOMMENDED }\end{array}$ & 100 sites & \\
\hline
\end{tabular}

\subsection{Recommended Survey Schedule}

Field surveys should be scheduled such that sites are visited when potential rare plant species area most visible, usually when they are flowering or fruiting. This approach ensures that most plants are seen when they are most visible and increases the possibility of observing unexpected species. Visits should be timed so that cool and warm season/ summer and winter annuals are in bloom.

A total of 20-25 days of field surveys is recommended to adequately cover the study area. It is predicted that approximately 4 sites can be visited per day, for a projected goal of up to 100 potential rare plant sites inventoried.

Field work should commence no earlier than mid-June. Table 3 presents a proposed general schedule for timing of field visits to each priority landscape type. It is recommended that 20 sites be surveyed in June, 40 sites in July, and 40 sites in August. Land-owners and lessees of the lands to be surveyed are to be contacted prior to commencement of the field work.

\subsection{FIELD METHODOLOGY}

\subsection{Survey Specifications}

The Alberta Native Plant Council (1997) Guidelines for Approaches to Rare Plant Surveys should be followed. Surveys should be floristic in nature. In a floristic survey, every plant is observed at a site and identified to the level that its rarity can be 
determined. For example, identifying a plant to genus (not species) may be adequate if that genus has no rare plants in it. Some rare plants are subspecies, so identifying only to species level would not be adequate in some situations.

In order to minimize overlap and maximize coverage, a systematic survey search pattern is recommended. Search patterns will depend on the topography and vegetation cover. Where conditions permit, walking a series of roughly parallel transects in a search unit will maximize coverage of the area. Search transects do not need to be marked unless convenient to serve as a short-term help to remember what areas have been covered. Survey intensity, or spacing of the transects, at each site needs to reflect the characteristics of the site. Where vegetation is very dense, with thick understory, a more intensive survey may be required. Where the site represents a well-defined landscape feature, such as a spring, the entire feature can be examined. Where the site represents a plant community which covers a large polygon, a representative area is delineated. Within that area, as much ground should be covered as is feasible to provide the greatest confidence that rare plants that occur there are observed.

Floristic surveys will have the objective of establishing the presence or absence of rare plants. At sites where no rare plants are recorded, numerical assessments of plant species (such as density estimates) are not required. However, at sites where rare plants are located, it is important to document the rare plant population (as described in Section 5.2 below), and collect detailed biophysical information about the rare plant's habitat (as described in Section 5.3).

\subsection{Documentation of Rare Plant Populations}

The documentation of a rare plant population is the most important step in a survey. The precise location is used for management decisions, ANHIC uses the occurrence data to make plant species status decisions and others such as herbaria receiving voucher specimens use the data to increase scientific understanding of rare plants.

\subsubsection{Rare Plant Survey Form}

An ANHIC Rare Native Plant Survey Form must be completed for each rare plant species population identified. This form includes spaces to record documentation information and location, habitat, population size and collector data.

Population data to record includes the number of plants, a description of their areal coverage and phenological data. The population size should be estimated by counting each individual if feasible. However, if the estimated number significantly exceeds 100 , a 0.5 metre Daubenmire frame can placed in a representative area of the population. The total number of individuals will then be estimated by extrapolation from the number within the frame. The areal extent of the population should also be estimated and recorded. 
The vigour of the rare plant population should also be noted. Good vigour is defined as having no sign of disease or stress, appearing healthy and with good colour. Any negative disturbances which may be affecting the survival of the species should be documented, including natural disturbances such as insect pests as well as land use threats such as grazing pressure.

\subsubsection{Location of Plots and Rare Plant Populations}

The location of all areas surveyed for rare plants should be marked on the aerial photographs by pin prick to represent the centre of the site. Record the site number on the back of the photo beside the pin prick, using black waterproof ink to mark the plot number. The survey plot locations and the rare plant locations must also be marked on 1:50,000 topographic maps.

In addition, rare plant populations will also be recorded on the aerial photo at the site pin prick, with a code number corresponding to that recorded on the Rare Native Plant Survey Form, in red waterproof on the back of the air photo.

Precise geographic co-ordinates should be determined in UTM by GPS. Determine the location of the centre of the population, or, in the case of elongate population distribution shape, record co-ordinates of edges of population. This information is then recorded on the Rare Plant Survey Form. Record directions to the site so that the plants can be easily relocated.

\subsubsection{Photographs and Voucher Specimens}

Rare plants and survey sites should be photographed with $35 \mathrm{~mm}$ colour print film. Photographs should be taken of the habitat, life form and diagnostic features (i.e. closeups of the flowers or fruits) of a rare plant to help with relocation and identification of the plant(s). Photographs can be a substitute for a voucher specimen. In addition, photos should be taken to portray the site in relation to surrounding landmarks, with compass cardinal points or bearings noted later on the prints.

A specimen of unknown plants can be collected for later identification but the ANPC collection guidelines should be followed used to decide under what conditions voucher specimens are taken. For non-vascular plants, standard collection practices should be followed, such as those outlined in Ireland (1982) and Schofield (1992).

If a voucher specimen will not be collected, measurements of leaf, flower and/or fruit width and length, and overall plant height should be recorded to assist in confirming identification.

Nomenclature and authorities should follow Moss (1983) for vascular plants, with exceptions as utilized by ANHIC; Anderson et al (1990) for brown mosses; Anderson (1990) for Sphagnum spp.; Stotler and Crandall-Stotler (1977) for liverworts; and Esslinger and Egan (1995) for lichens. Any other references used to key species should 
be stated. To ensure proper identification of rare species, a taxonomic expert should review all specimens and photographs.

\title{
5.3 Rare Plant Site Descriptions
}

It is important to have a general plant community description to place any rare species found within a community context. When the entire habitat supporting a rare plant species is documented in rare plant surveys, more consistent data is collected among sites. In addition, this information helps to clarify the ecological requirements of rare plant species. For example, for non-vascular plants, it is important to document both the micro-habitat, such as the soil or rock substrate on which a bryophyte grows, and the "meso-habitat", such as the streambank on which it is found.

A nested relevé method should be used to establish plot sizes for plant community type description at sites where rare plants area found. Plots should be $400 \mathrm{~m}^{2}$ for trees, and $100 \mathrm{~m}^{2}$ for other plant species. Field data should be recorded on Alberta Environment's current Site Description and Vegetation Description forms. Forms should be completed according to guidelines in the Ecological Land Survey Site Description Manual (Alberta Environmental Protection 1994). Coding for plant species on the Vegetation form should be based on Alberta Environmental Protection (1993 or newer). The biophysical information collected at each rare plant site will be later utilized for a vegetation community classification of the site.

\subsection{RARE PLANT REPORT AND OTHER RECEIVABLES}

\subsection{Report Specifications}

The rare plant survey report should contain, at a minimum, the following sections:

\author{
ABSTRACT \\ INTRODUCTION \\ STUDY AREA DESCRIPTION (including location, climate, biophysical \\ characteristics, land use) \\ METHODS \\ RESULTS - including:
}

- total number and description of sites visited;

- results of surveys at these sites, including:

Summaries of rare plants found

Tables of vascular and non-vascular rare plants identified during this study, with Provincial and Global rank, dates of observation, general habitat;

- description of the rare plants found, including numbers, extent, vigour and location;

Analysis of habitat preferences (summary of habitats where rare plants were found)

Detailed discussion of each species observation 
Anomalies

- description of the site conditions where rare plants were found, including plant community types. Beckingham et al (1996) classify Lower Foothills community types within an ecosite hierarchy, and it is recommended that this document be used as a basis for description of plant communities where rare plants are found. The following reports may also be useful in identifying plant community types in the study area: Bentz et al (1993); Van Waas (1978); Lane et al (2000); Environmental Management Associates (1993) and Downing (1999). Several soil surveys have been completed in the study area, and these should also be consulted, including Lesko and Lindsay 1973, Lindsay et al 1958, Twardy and Lindsay 1971 and Wynnyk et al 1969.

- Maps - to include location of survey sites, and observed rare plant occurrences, as well as a legend

DISCUSSION AND RECOMMENDATIONS- including but not limited to:

- problems with methodology;

- comparison with previous rare plant data

- recommendations for management of rare plant populations at each site, especially if imminent threats were noted

- further studies recommended

\section{LITERATURE CITED}

APPENDICES - such as:

- photographs of rare plants and their habitats. Photographs should be appropriately captioned.

- definitions of rare plant ranking systems

\subsection{Summary of Receivables}

- Annotated aerial photographs and maps with sites surveyed and rare plant populations

- Completed Rare Native Plant Survey Forms

- Annotated plant specimens and photographs

- Completed Site and Vegetation Description Forms for sites where rare plants were recorded

- Draft and final versions of report

\subsection{PROJECT CONSIDERATIONS AND CONSTRAINTS}

Project considerations and constraints include:

- Surveyors must have experience as botanical field investigators, and the taxonomic experience to identify most plant species they come across in the study area, either in 
the field or later through taxonomic determination (ANPC 1997). A knowledge of plant ecology and of the local flora is also important.

- With time and budget constraints and a relatively large area to be covered, it is recommended that a field work plan be flexible. Field researchers must be prepared to change the field plan, for example, expand the search area, if rare plants are found.

- Predicting the occurrence of rare plants is an intuitive and subjective process. Much ground may have to be searched before rare plants are found.

- Floristic surveys proceed slowly at first, but speed up as the time required for plant identification is reduced. Researchers need to study herbarium specimens of rare plant species with the potential to occur in the study area, to create a search image.

- Survey intensity should reflect the characteristics of the site, and will likely vary from site to site, depending on such factors as density of vegetation, terrain, and the visibility of expected rare plant species.

- Although it takes time to record biophysical information at the rare plant sites, habitat and plant community type information assists with future rare plant surveys in similar study areas.

- Voucher specimens should only be taken when the immediate population can withstand the removal of the individual ( $<4 \%$ loss; ANPC 1997).

- The relative abundance of any species varies annually, and in some unfavourable seasons, some rare species may not be visible. For example, some species will not flower in dry years, making them difficult to spot and to identify; above ground growth may even be absent some years. Thus, sometimes even very thorough rare plant surveys would not discover a rare plant occurring on a site. Thus a rare plant survey cannot confirm a plant's absence, only its presence.

- Other factors such as grazing and insects can also decrease the visibility of rare plants on a site.

- Because of annual variation, rare plant surveys should optimally be conducted over more than one flowering season.

- Because of the possibility of damage to the rare plant population, marking the rare plant occurrence locations is not recommended.

- All rare plant occurrences should be reported to the Alberta Natural Heritage Information Centre for inclusion in their database. 


\subsection{LITERATURE CITED}

Achuff, P.L. 1994. Natural regions, subregions and natural history themes of Alberta.

Prep. for Parks Services, Alberta Environ. Prot. Edmonton.

Alberta Environmental Protection. 1994. Ecological land survey site description manual. Canada-Alberta Partnership Agreement in Forestry. Edmonton.

Alberta Environmental Protection. 1993. Alberta plants and fungi- master species list and species group checklists. Pub. No. Ref. 75. Edmonton.

Alberta Native Plant Council. 1997. Ed. by J. Lancaster. Guidelines for Rare Plant Surveys. $6 \mathrm{pp}$.

Anderson, L.E. 1990. A checklist of Sphagnum in North America north of Mexico. The Bryologist 93: 500-501.

Anderson, L.E., H. Crum and W.R. Buck 1990. List of the Mosses of North America, North of Mexico. Bryologist 93(4): 448-499.

ANHIC (Alberta Natural Heritage Information Centre). 2000. Plant species of special concern. Compiled by Joyce Gould.

Beckingham, J.D., I.G. Corns and J.H. Archibald. 1996. Field guide to ecosites of westcentral Alberta.

Bentz, J. and A. Saxena. 1994. Significant ecological features inventory of the Whitecourt - Swan Hills Integrated Resource Planning Area. Prep. for Alberta Environ. Prot. Edmonton.

Bentz, J.A., A. Saxema and T. Normand. 1995. Environmentally significant areas inventory - Foothills Natural Region, Alberta. Prep. for Alberta Environ. Prot, Edmonton. 140 pp. plus appendices.

Bentz, J., D. O'Leary and A. Saxena. 1993. Ecological land classification of the Whitecourt - Swan Hills Integrated Resource Planning Area. Prep. for Alberta Environ. Prot. 138 pp.

Downing, D. 1999. Summary: Eastern Slopes Region Benchmark Program Results 1993-1998. Prep. for Alberta Environ. Prot/ Alberta Agric., Food and Rural Development. Edmonton.

Environmental Management Associates. 1993. Deciduous forest types of the Lower Boreal Cordilleran Ecoregion, West-central Alberta: first approximation. Prep. for Alberta Forestry, Lands and Wildlife. Edmonton. 
Esslinger, T.L and R.S. Egan. 1995. A sixth checklist of the lichen-forming, lichenicolous and allied fungi of the continental United States and Canada. The Bryologist 98: 467-549.

Hudson, J.H. 1977. Carex in Saskatchewan. Bison Publishing House, Saskatoon, Saskatchewan.

Ireland, R.R. 1982. Moss flora of the Maritime Provinces. National Museum of Natural Sciences, Public. of Botany No. 13. Ottawa.

Johnson, D., L. Kershaw, A. MacKinnon and J. Pojar. 1995. Plants of the western boreal forest and aspen parkland. Lone Pine Publishing, Edmonton.

Lane, C., M. Willoughby and M. Alexander. 2000. Range plant community types and carrying capacity for the Lower Foothills Subregion of Alberta. $3^{\text {rd }}$

Approximation. Alberta Environ. and Alberta Agric., Food and Rural Development, Edmonton.

Lesko, G.L. and J.D. Lindsay. 1973. Forest/soil relationships and management considerations in a portion of the Chip Lake map area, Alberta. Alberta Research Council, Earth Sciences Report 73-1. Edmonton.

Lindsay, J.D., S. Pawluk and W. Odynsky. 1958. Exploratory soil survey of Alberta map sheets 84D (north half), 84E, 84F and 84G. Alberta Research Council Preliminary Soil Survey Report 59-1. Vegreville.

Moss, E.H. 1983. Flora of Alberta. $2^{\text {nd }}$ Edition. Univ. of Toronto Press, Toronto.

Schofield, W. 1992. Some common mosses of British Columbia. Royal British Columbia Prov. Museum handbook. ISSN 1188-5114.

Stotler, R. and B. Crandall-Stotler. 1977. A checklist for the liverworts and hornworts of North America. The Bryologist 80: 405-428.

Timoney, K. and A.Robinson. 1998. A floristic and landscape survey of the Ft. Assiniboine Sandhills Wildland Park. Prep. for Alberta Environ. Prot., Edson.

Twardy, A.G. and J.D. Lindsay. 1971. Reconnaissance soil survey of the Chip Lake Area. Report S 71-28, Soils Div., Alberta Research Council, Vegreville.

Van Waas, C. 1978. Biophysical analysis and evaluation of capability, Whitecourt area. Alberta Energy and Natural Resources. ENR Report No. 61. Edmonton.

Vitt, D.H., J.E. Marsh and R.B. Bovey. 1988. Mosses, lichens and ferns of northwest North America. Lone Pine Publishing. Edmonton. 
Vitt, D. 1992. The peatlands of Alberta: a 1:1,000,000 summary map, edited by B. Nicholson and L. Halsey. Alberta Forestry, Lands and Wildlife, Edmonton.

Vitt, D., L. Halsey, M. Thormann and T. Martin. 1998. Peatland inventory of Alberta. Prep. for Alberta Peat Task Force. Univ. of Alberta, Sustainable Forest Management, Edmonton.

Wynnyk, A., J.D. Lindsay and W. Odynsky. 1969. Soil survey of the Whitecourt and Barrhead Area. Report No. 27. Soils Div. Alberta Research Council, Vegreville. 

APPENDIX A. Rare vascular plants with the potential to occur in the study area. (based primarily on information in Moss 1983, unless otherwise specified).

\begin{tabular}{|c|c|c|c|}
\hline Species & Common Name & SRank & Habitat \\
\hline Botrychium simplex & dwarf grape fern & $\mathrm{S} 2$ & $\begin{array}{l}\text { moist meadows and shores; central Alberta (Moss } \\
\text { 1983) }\end{array}$ \\
\hline Cardamine pratensis & meadow bitter cress & S1S2 & $\begin{array}{l}\text { moist meadows and swamps, central and western } \\
\text { Alberta (Moss 1983) }\end{array}$ \\
\hline Carex arcta & narrow sedge & S1 & $\begin{array}{l}\text { moist woods (Moss 1983); marshes, fens and } \\
\text { swamps (Johnson et al 1995); }\end{array}$ \\
\hline Carex capitata & capitate sedge & S2 & boggy, often calcareous areas \\
\hline Carex heleonastes & Hudson Bay sedge & S2 & $\begin{array}{l}\text { bogs and marshes, often calcareous; (Moss 1983); } \\
\text { open sunny non-acid bogs (fens) (Hudson 1977) }\end{array}$ \\
\hline Carex lacustris & lakeshore sedge & S2 & $\begin{array}{l}\text { rich fen with Carex lasiocarpa / Drepanocladus } \\
\text { revolvens }\end{array}$ \\
\hline Dryopteris cristata & crested shield fern & S1 & $\begin{array}{l}\text { moist woods and marshes; } 1 \text { dot in Moss } 1983 ; \\
\text { central Alberta }\end{array}$ \\
\hline Eleocharis tenuis & slender spike-rush & SU & $\begin{array}{l}\text { prob. var. borealis; not in Moss (1983); ranked SU } \\
\text { because of taxonomic confusion between it, } E \text {. } \\
\text { compressa and } E \text {. elliptica (ANHIC files); marshy } \\
\text { places; }\end{array}$ \\
\hline Juncus filiformis & thread rush & S2S3 & bogs, marshes \\
\hline $\begin{array}{l}\text { Juncus stygius var. } \\
\text { americanus }\end{array}$ & marsh rush & S2 & bog pools \\
\hline Malaxis monophylla & white adder's-mouth & S2 & $\begin{array}{l}\text { damp woods, banks and bogs ; bogs ; in mature } \\
\text { riparian mixedwood forests (Timoney and Robinson } \\
\text { 1998) }\end{array}$ \\
\hline Malaxis paludosa & bog adder's-mouth & S1 & wet bogs, in Sphagnum moss (central Alberta) \\
\hline Parnassia parviflora & $\begin{array}{l}\text { small northern grass-of- } \\
\text { parnassus }\end{array}$ & S2 & bogs and stream banks; \\
\hline $\begin{array}{l}\text { Rhynchospora } \\
\text { capillacea }\end{array}$ & slender beak-rush & S1 & calcareous bogs (Moss 1983); fens (Vitt et al 1998) \\
\hline Trichophorum pumilum & dwarf bulrush & S2 & $=$ Scirpus pumilus of Moss 1983 ; calcareous bogs; \\
\hline
\end{tabular}


APPENDIX B. Other bryophytes predicted to occur in the study area (based on Vitt et al 1998).

\begin{tabular}{|l|l|l|}
\hline Species & SRank & Habitat \\
\hline Anastrophyllum michauxii & S1 & bogs \\
\hline Calypogeja muelleriana & S? & bogs \\
\hline Cephaloziella hampeana & S? & bogs \\
\hline Cephaloziella rubella & S? & poor fens \\
\hline Cephaloziella subdentata & S? & bogs \\
\hline Gymnocolea inflata & S1 & poor fens \\
\hline Lophocolea bidentata & S? & bogs \\
\hline Lophozia capitata & S1 & bogs, extreme-rich fens \\
\hline Moerckia hibernica & S1S2 & extreme-rich fens \\
\hline Odontoschisma denudatum & S1 & bogs, extreme-rich fens \\
\hline Pseudobryum cinclidioides & S1 & bogs, poor fens, and swamp \\
\hline Riccardia latifrons & S? & bogs \\
\hline Riccia fluitans & S? & medium-rich fens, marsh \\
\hline Sphagnum compactum & S1S2 & extreme-rich fens \\
\hline Sphagnum contortum & S1 & extreme-rich fens \\
\hline Sphagnum fallax & S2 & bogs, poor fens \\
\hline
\end{tabular}


APPENDIX C. Aerial photography coverage and Alberta Vegetation Inventory available for the study area.

I. Aerial photography available for study area from government sources ${ }^{1}$ :

\begin{tabular}{|l|l|l|l|}
\hline $\begin{array}{c}\text { Job } \\
\text { Number }\end{array}$ & \multicolumn{1}{|c|}{ Scale } & Year & \multicolumn{1}{c|}{ Area covered } \\
\hline $95-144$ & $1: 30,000$ & 1995 & all except northwest part of study area \\
\hline $95-29$ & $1: 20,000$ & 1995 & $\begin{array}{l}\text { northwest part of study area (including areas } \\
\text { missed by 95-144) }\end{array}$ \\
\hline $95-96$ & $\begin{array}{l}\sim 1: 50,000 \\
\text { (scale varies) }\end{array}$ & 1995 & $\begin{array}{l}\text { approximately the north half of study area (NOTE: } \\
\text { scale of photos varies) }\end{array}$ \\
\hline
\end{tabular}

${ }^{1}$ Note: additional photography available for smaller sections of the study area; also potentially available from private sources.

II. Alberta Vegetation Inventory (AVI) completed for study area*:

\begin{tabular}{|l|l|l|}
\hline Township & $\begin{array}{l}\text { Ranges } \\
\text { (W5M) }\end{array}$ & Comments \\
\hline 53 & $11-14$ & $\begin{array}{l}\text { AVI not completed for small } \\
\text { portion of southeast part of study } \\
\text { area }\end{array}$ \\
\hline 54 & $9-14$ & \\
\hline 55 & $8-14$ & \\
\hline 56 & $8-14$ & \\
\hline 57 & $8-14$ & Range 14 done by FMA holder \\
\hline 58 & $8-13$ & Range 14 done by FMA holder \\
\hline 59 & $8-13$ & \multicolumn{2}{|l}{} \\
\hline
\end{tabular}

(*C. Lommerse/D.Langner, Resource Data Div., Alberta Environ., pers.comm.) 


National Library of Canada

Bibliotheque nationale du Canada

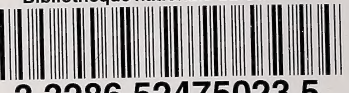

33286524750235 